\title{
SWINE INFLUENZA SURVEILLANCE AND THE IMPACT OF HUMAN INFLUENZA EPIDEMICS ON PIG HERDS IN THE CZECH REPUBLIC
}

\author{
Z. POSPÍŠIL ${ }^{1}$, P. LÁNY ${ }^{1}$, B. TƯMOVÁ ${ }^{2}$, J. BUCHTA $^{1}$, D. ZENDULKOVÁ ${ }^{1}$, P. ČÍHAL $^{1}$ \\ ${ }^{1}$ Department of Infectious Diseases and Veterinary Epidemiology, University of Veterinary and Pharmaceutical \\ Sciences, Brno, Czech Republic \\ ${ }^{2}$ National Institute of Public Health, Prague, Czech Republic
}

Received April 24, 2001

Accepted August 28, 2001

Abstract

Pospíšil Z., P. Lány, B. Tůmová, J. Buchta, D. Zendulková, P. Č́ihal: Swine Influenza Surveillance and the Impact of Human Influenza Epidemics on Pig Herds in the Czech Republic. Acta Vet. Brno 2001, 70: 327-332.

Epizootiological and virological surveys carried out between 1995 and mid-2000 corroborated the findings from the end of the 1970s that swine influenza did not cause any serious problems in pig herds in the Czech Republic. In the present study, no antibodies against either swine influenza virus, types $\mathrm{A}(\mathrm{H} 1 \mathrm{~N} 1)$ and $\mathrm{A}(\mathrm{H} 3 \mathrm{~N} 2)$, or avian influenza virus, $\mathrm{A}(\mathrm{H} 1 \mathrm{~N} 1)$, were demonstrated and no influenza virus was isolated. In contrast, antibodies against the human influenza virus isolated during the 1995 epidemic were found. The dynamics of antibody formation indicated that the human virus did not become established, long-term, in the pig population but gradually disappeared. It is possible that the human virus was introduced to the pig herds by infected animal attendants, in whom antibodies against this virus were also found. During the second human influenza epidemic in $1998 / 99$, however, pigs remained free from antibody response to influenza virus.

Influenza virus, antibodies, swine, human, epidemiology

Swine influenza was a serious health problem in pig herds in the former Czechoslovakia in the 1950s and 1960s. In this period, large-scale intensive animal production was initiated and, on large farms, swine influenza affected both suckling piglets, causing direct losses, and weaned pigs. In older pigs, it predisposed to sensitivity to a whole range of bacteria and, consequently, to the development of severe chronic diseases.

At that time, Menšík (1960) and Goiš et al. (1963) were the specialists who isolated a number of influenza virus strains and carried out a series of experiments on the pathogenesis of the disease. Shortly after Ku n in (1970) had reported the occurrence of human influenza in pigs, experimental infections with A/Hong Kong virus were initiated in specific pathogen free piglets (Pospíšil et al. 1973) in an attempt at virus adaptation (Menšík et al. 1976) and to demonstrate the production of antibodies to human influenza strains in pigs (Tůmová et al. 1976; 1980).

Investigations carried out in the following years showed that swine influenza disappeared almost completely from our pig herds and the disease itself presented no health risk for pigs. This situation was still true even at the time of first reports on avian influenza viruses infecting pigs (Pen s aert et al. 1981). Even later, when pig infections with influenza viruses of avian origine were described in Italy (Castrucci et al. 1993) and Germany (Ludwig et al. 1994), swine influenza did not seem to play any important role in the health status of Czech pig herds. However, it should be admitted that this disease had not been kept under full surveillance at that time. Therefore, a single isolation of swine influenza virus reported by Šesták (1992, personal communication), which did not involve any epidemiological survey, can now be regarded as a chance event.

The domestic pig plays a specific role in the spread of influenza viruses because, owing to common receptors on the epithelial cells of the respiratory system, it is the only animal

Address for correspondence:

Prof. MVDr. Zdeněk Pospíšil, DrSc

University of Veterinary and Pharmaceutical Sciences

42 Brno
Phone: +420541562305

Fax: +420 541562014

http://www.vfu.cz/acta-vet/actavet.htm 
species that can be infected with both avian and human influenza viruses (Kida et al. 1994; Ito et al. 1996). The pig functions as a kind of "mixing vessel" in which recombination events and changes in antigenic structures of the viruses take place, thus giving rise to recombinants that may initiate new epidemics or pandemics.

In this continuing study, in addition to the detection of swine influenza virus or antibodies against it, we also investigated the impact of two human influenza epidemics on the animal populations.

\section{Materials and Methods}

Virus strains

The following strains were used in serological tests:

a) swine influenza viruses A/Sw/Brno 2/75 (H1N1); A/Sw/Germany 2/81 (H1N1), A/Sw/Brno 2/92 (H1N1); $\mathrm{A} / \mathrm{Sw} / \mathrm{Gent} / 86$ (H3N2); A/Sw/Germany/91 (H3N2);

b) influenza viruses of avain origine isolated from pigs: A/Sw/Germany 8533/91 (H1N1) and A/Sw/Italy 45/79 (H1N1);

c) human influenza viruses A/Oystercat/Germany/87 (H1N1); A/Praha 625/95 (H3N2), isolated during the December 1995 epidemics of human influenza, and A/Plzeň 925/99 (H3N2), isolated during human influeza epidemics in January 1999.

All the strains, with the exception of A/Sw/Gent/86, are maintained in the National Human Influenza Reference Laboratory (National Institute of Public Health, Prague, Czech Republic). The A/Sw/Gent/86 strain was donated by the University of Veterinary Medicine, Vienna, Austria.

Pigs examined

Animals included in the group examined were of different age and came from various herds; they all had clinical or pathomorphological findings of respiratory disease. Nasal swabs or samples of inflamed pulmonary tissue were collected for virus isolation experiments. For serological tests, blood drawn from the jugular vein was used.

In the respective periods of human influenza epidemics (winter in 1995/96 and 1998/99) and in the subsequent months, the study on inter-species transfer of virus infection was carried out, using sera from pigs of breeding herds. These sera came from the samples that are regularly collected from breeding sows and boars in the programme of animal health surveillance and are examined for specific swine diseases before the animals are sold. A total of 1353 samples were used.

In one of the locations studied, we also acquired sera from animal attendants who had been taken ill during the first influenza epidemic.

Virus isolation

Nasal discharge collected by means of sterile swabs and maintained in a transport medium, or a $10 \%$ pulmonary tissue suspension in E-MEM medium without serum but supplemented by 500 I.U. penicillin and $500 \mathrm{mg}$ streptomycin per ml were centrifuged at $1500 \mathrm{~g}$ for $15 \mathrm{~min}$. They were either used to inoculate chick embryos or were stored at $-70^{\circ} \mathrm{C}$ until use.

In order to isolate the virus, the treated infectious material was inoculated into allantoid sacs of 9-day-old chick embryos and incubated for $72 \mathrm{~h}$. They embryos were checked every day. Before collection of allantoid fluid, the embryos were cooled down to $+4^{\circ} \mathrm{C}$, and the fluid examined by the haemagglutination test (HI) using $1 \%$ chicken erythrocytes.

Serological examination

Antibodies were detected by the haemagglutination-inhibition test (HIT carried out in U-bottom microtitre plates). Serial twofold dilutions of the $0.025 \mathrm{ml}$ test serum sample were mixed with equal volumes of the virus in allantoid fluid, each containing four haemagglutination-inhibition units, and the mixtures were incubated at room temperature for $40 \mathrm{~min}$. Subsequently, $0.05 \mathrm{ml}$ of $1 \%$ chicken erythrocytes were added. The results were read after 40 to $60 \mathrm{~min}$. Before the examination, all test sera were treated with the receptor-destroying enzyme.

\section{Results}

The examination of 1353 serum samples, collected during the period from 1995 to mid2000, for antibodies against swine influenza A (H1N1) and A (H3N3) viruses did not show any antibodies in HIT that would indicate the presence of infection by these two serotypes of influenza viruses. Negative results were also obtained from the examination of sera for avian influenza viruses isolated from pigs.

Attempts at isolating influenza viruses in chick embryos also failed to give positive results. All samples of allantoid fluid from the chick embryos inoculated with nasal swabs or lung tissue suspensions gave negative results in the HI test. 
Tests to demonstrate antibodies against human influenza virus A/Prague 625/95 (H3N2) were carried out in the pig sera collected in the first half of 1996. This strain was isolated during the epidemic that peaked at the end of 1995.

Table 1

Results of serological examination for human influenza A/Prague 625/95 (H3N2) virus in pig sera

\begin{tabular}{|c|c|c|c|c|c|c|}
\hline \multirow[b]{2}{*}{ Farm } & \multirow[b]{2}{*}{ Result } & \multicolumn{5}{|c|}{ Date of collection } \\
\hline & & $\begin{array}{c}\text { Dec. } 11 \\
1995\end{array}$ & $\begin{array}{c}\text { January } 23 \\
1996\end{array}$ & $\begin{array}{c}\text { April } 1 \\
1996\end{array}$ & $\begin{array}{l}\text { July } 1 \\
1996\end{array}$ & $\begin{array}{c}\text { November } 19 \\
1996\end{array}$ \\
\hline & & No. of sera & No. of sera & No. of sera & No. of sera & No. of sera \\
\hline \multirow{2}{*}{ A } & Total & 25 & 63 & 40 & 37 & 32 \\
\hline & Positive & 0 & 37 & 17 & 0 & 0 \\
\hline \multirow{2}{*}{ B } & Total & 36 & 23 & 40 & 158 & Not tested \\
\hline & Positive & 0 & 22 & 8 & 0 & \\
\hline \multirow{2}{*}{$\mathrm{C}$} & Total & 50 & 53 & 30 & 25 & Not tested \\
\hline & Positive & 0 & 24 & 24 & 0 & \\
\hline \multirow{2}{*}{$\mathrm{D}$} & Total & 15 & 15 & Not tested & Not tested & Not tested \\
\hline & Positive & 0 & 0 & & & \\
\hline \multirow{2}{*}{$\mathrm{E}$} & Total & 15 & 15 & Not tested & Not tested & Not tested \\
\hline & Positive & 0 & 0 & & & \\
\hline \multirow{2}{*}{$\mathrm{F}$} & Total & 15 & 15 & Not tested & Not tested & Not tested \\
\hline & Positive & 0 & 0 & & & \\
\hline \multirow{2}{*}{$\begin{array}{l}\text { Attendants } \\
\text { On Farm A }\end{array}$} & Total & Not tested & Not tested & 6 & Not tested & Not tested \\
\hline & Positive & & & 4 & & \\
\hline
\end{tabular}

Out of six herds, which were under surveillance in Moravia at that time, three showed the presence of antibodies. Tables 1 and 2 show that, in December 1995, all herds were still free from antibodies. However, when serum samples were collected at the end of January 1996, most of the animals examined exhibited specific antibodies at titres ranging from 1:20 to 1:320. At the next collection in April 1996, the number of animals with positive findings was markedly lower, as were the titre values, ranging between 1:10 and 1:40. None of the sera obtained by July, 1, 1996, gave positive results

Table 2

Antibody titres in positive serum samples

\begin{tabular}{|c|c|c|}
\hline Farm & Titres* on January 23,1996 & Titres* on April 1, 1996 \\
\hline A & $1: 80-160(1: 20-320)$ & $1: 10-20(1: 10-40)$ \\
\hline B & $1: 40-160(1: 20-160)$ & $1: 10-20(1: 10-40)$ \\
\hline C & $1: 20-160(1: 10-160)$ & $1: 10-20(1: 10-40)$ \\
\hline Attendants, A & Not tested & $1: 20(1: 10-20)$ \\
\hline
\end{tabular}

*Most frequently found titre values, with the range given in brackets. 
Specific antibodies against human influenza virus A/Prague 625/95 (H3N2) were detected in four of six animal attendants on farm A. At a single serum collection in April 1996, antibody titres showed values of 1:20 to 1:40 (Table 2). These attendants reported being ill with an influenza-type disease in December 1995.

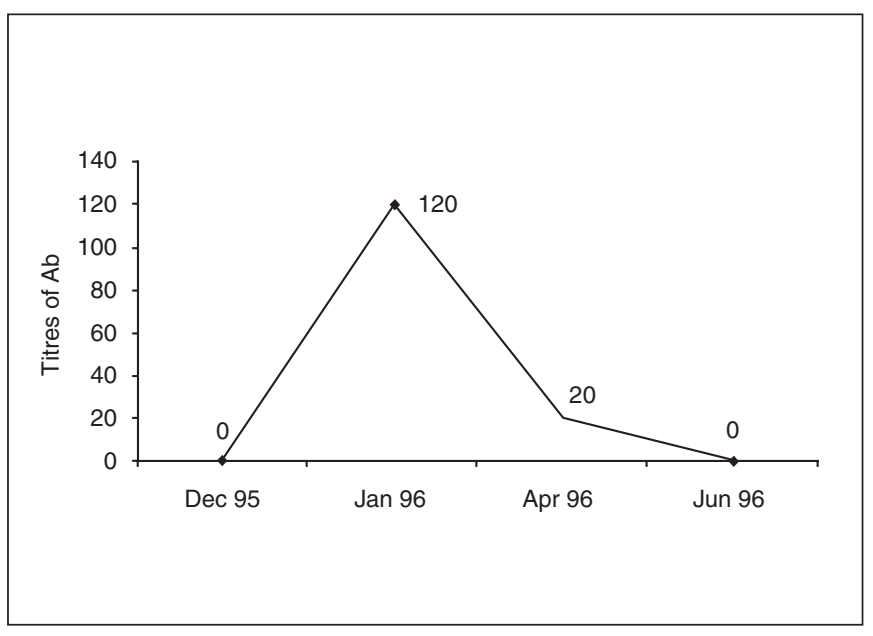

Fig 1: Dynamics of the titres of antibodies against human influenza virus A/Prague 625/95 (H3N2) in pigs
Some response to the human influenza epidemic that broke out at the turn of 1998/99 was also expected in the pig herds. Therefore, 670 serum samples from nine pig herds, representative of the whole Czech Republic, were tested against the A/Plzen̆ 925/99 (H3N2) virus isolate. The sera examined gave negative results in the tests with this as well as the other influenza viruses isolated from pigs, as reported above.

\section{Discussion}

Our epizootiological survey from the mid-1990s confirmed the findings made at the end of the 1970s which showed that there were no economic losses or health problems due to swine influenza in pig herds (Menšík et al. 1979). In the period from 1995 to mid-2000, no antibodies were demonstrated against either the swine influenza virus type A (H1N1) or the type A (H3N2) in the Czech and Moravian herds examined. Nor was any influenza virus isolated from the pigs of these herds. Only as late as in the second half of 2000, at the time this study was being prepared Buchta and Lány and others isolated an influenza virus from pigs of one herd. On the basis of preliminary experiments, this virus was identified as $\mathrm{A}(\mathrm{H} 1 \mathrm{Nx})$; the results will be reported in a subsequent publication.

In the present study we failed to demonstrate antibodies against influenza viruses of avian origin that were frequently present in pig herds in Belgium, Italy and Germany at the beginning of the 1990s (Pensaert et al. 1981; Castrucci et al. 1993; Ludwig et al. 1994). However, in three of the pig herds, we did find antibodies against human influenza virus A/Prague 625/95 (H3N2) which was isolated from humans during the 1995 influenza epidemic. Because the antibodies in pig sera were associated with the human epidemic, it is assumed that the pigs came in contact with the virus through the attendants who had influenza. This assumption is supported by the presence of specific antibodies in four employees of one farm (A), which were found by an examination on a single occasion 4 months after the epidemic, and by the statements of employees that they continued to look after the animals even after the onset of their own disease.

However, the dynamics of antibody formation shows that the human influenza virus did not become established, long-term, in the pig population but gradually disappeared. All piglets born after the human epidemic and examined 6 months later had negative serological findings. In contrast, we did not find any impact of the second epidemic of human influenza at the turn of 1998/99 on pig herds, although the sera were tested against the 1999 influenza strain A/Plzeň 925/99 (H3N2). 
The pig, as the only animal species sensitive to infection with avian or human influenza viruses, can play an important role in the epidemiology of influenza because it can provide a medium in which recombinations of different A type influenza viruses can take place (Webster et al. 1992; Scholtis sek et al. 1993; Lange et al. 2000).

According to Webster et al. (1992), the influenza virus A (H1N1) that, in 1918/1919, caused the most severe influenza pandemic ever reported was of avian origin. Since, at that time, pigs were also reported to be ill, it could be speculated that the recombination mentioned above may have occurred in the pig population before the human population was infected. However, unambiguous evidence for this assumption has not yet been found. Some support may be provided by the most recent findings from Hong Kong where, in 1997, poultry were affected by a severe epizootic that was caused by an avian influenza virus, subtype H5N1. In association with this epizootic, the first cases of the direct transmission of avian influenza to humans were recorded; fortunately, they were without a tendency to spread and the reason for this may have been the absence of propagation of the virus in the pig population (Lange et al. 2000).

Some cases of human disease due to swine influenza virus have also been described (Gaydos et al. 1977; Hodder et al. 1977; O'Brien et al. 1977). The best known of them is the disease that broke out in the Fort Dix Military Training Centre, New Jersey, USA, where 230 soldiers were infected with the A/New Jersey/1976 (H1N1) virus and one of them died. This infection, fortunately, developed into neither epidemic nor pandemic.

Although, at present, swine influenza is not a serious epizootiological issue in the Czech Republic, occasional reports of the isolation of influenza virus or the presence of antibodies against it in pig herds signal some potential danger. Information from some European countries about the circulation of influenza viruses in both human and pig populations has kept virologists and epidemiologists vigilant because, at any time, new subtypes might arise and an influenza pandemic might ensue.

\section{Surveillance influenzy prasat a odraz humánní chřipkové epidemie $v$ chovech prasat $v$ České republice}

Epizootologické a virologické šetření, probíhající od roku 1995 do poloviny roku 2000, potvrdilo poznatky z konce 70 . let, že influenza prasat nepůsobí v chovech prasat České republiky žádné závažné problémy. Nebyly prokázány ani protilátky proti virům influenzy prasat typu $\mathrm{A}(\mathrm{HIN} 1)$ a $\mathrm{A}(\mathrm{H} 3 \mathrm{~N} 2)$, ani proti influenzovým virům ptačího původu $\mathrm{A}(\mathrm{H} 1 \mathrm{~N} 1)$, které byly v posledních letech frekventní u prasat v některých zemích Evropy. Rovněž nebyl izolován žádný influenzový virus. Naproti tomu jsme prokázali protilátky proti humánnímu influenzovému viru, který byl izolován př̀i epidemii lidské chřipky koncem roku 1995. Sledování dynamiky protilátek ukázalo, že se chřipkový virus v populaci prasat neuchytil a postupně vymizel. Virus do chovu prasat zavlekli pravděpodobně nemocní ošetřovatelé, u nichž byly protilátky proti stejnému viru rovněž prokázány. Při další chřipkové epidemii na přelomu let 1998/99 jsme podobnou protilátkovou odezvu nezaznamenali. Je diskutován výjimečný význam prasat $\mathrm{v}$ epidemiologii a ekologii chřipkových virů.

\section{Acknowledgements}

This work was supported by the Grant Agency of the Czech Republic, project No. 524/99/1226 and the Research project of The Ministry of Education, Youth and Sports of the Czech Republic, project No. MSM 161700001.

\section{References}

CASTRUCCI, M. R., DONATELLI, I., SIDOLI, L., BARIGAZZI, G. KAWAOKA, Y., WEBSTER, R. G. 1993: Genetic Reassortment between Avian and Human Influenza A Viruses in Italian Pigs. Virology, 193: 503-506 GAYDOS, J.C., HODDER, R. A. 1977: Swine influenza A at Fort Dix. J. Infect. Dis. 136: 356-368 
GOIŠ, M., MENŠK, J., DAVIDOVÁ, M., MESÁROŠ, E., JURMANOVÁ, K. 1963: Attempt to standardize technique used isolating influenza virus from pig lungs. Acta Virol. 7: 455-464

HODDER, R. A., GAYDOS, J.C., ALLEN, R.G., TOP, F.H. 1977: Swine influenza A at Fort Dix, New Jersey. III. Extend of spread and duration of the outbreak. J. Infect. Dis. 136: 369-375

ITO, T., KIDA, T., KAWAOKA, Y. 1996: Reports of influenza A viruses. In: Brown L.E. et al. (Eds.) Options for the control of influenza III., Elsevier Science B.V.: pp. 516-519

KIDA, H., ITO, T., YASUDA, J., SHIMIZU, Y., ITAKURA, C., SHORTRIDGE, K. F., KAWAOKA, Y., WEBSTER, R.G. 1994: Potential for transmission of avian influenza viruses to pigs. J. Gen. Virol. 75: 21832188

KUNDIN, W. D. 1970: Hong Kong A-2 influenza virus infection among swine during a human epidemic in Taiwan. Nature 228: 857-867

LANGE, W. 2000: Pferdeinfluenza: Virologie, Epidemiologie, Klinik, Therapie und Prophylaxe. Parey Buchverlag, Berlin, $190 \mathrm{p}$.

LUDWIG, S., HAUSTEIN, A., KALETA, E. F., SCHOLTISSEK, C. 1994: Recent influenza A (H1N1) infections of pigs and turkeys in northern Europe. Virology 202: 281-286

MENŠIK, J., 1960: The production and dynamisms of antibodies in swine influenza. Vet. Med. Praha 5: 599-610

MENŠÍK, J., POSPÍŠIL, Z., MACHATKOVÁ, M., TĚMOVÁ, B., FRANZ, J., ŠTUMPA, A. 1976: Adaptation of human influenza A/Hong Kong/68 (H3N2) virus to colostrum deprived. specific-pathogen-free piglets. Zbl. VetMed. B 23: 638-651

MENŠ́́K, J., VĚŽNÍKOVÁ, D., POSPÍŠIL, Z., FRANZ, J., MACHATKOVÁ, M. 1979: Occurrence of influenza A viruses in pigs in the last 10 years. (Project report), Brno, Veterinary Research Institute, $37 \mathrm{p}$.

O'BRIEN, R. J., NOBLE, G. R., EASTERDAY, B. C., KENDAL, A. P., SHABY D. M. 1977: Swine like influenza virus infection in a Wisconsin farm family. J. Infect. Dis. 136: 390-396

PENSAERT, M., OTTIS, K., VANDEPUTTE, J., KAPLAN, M. M., BACHMANN, P.A., 1981: Evidence for the natural transmission of influenza A virus from wild duck to swine and its potential importance for man. Bull. WHO 59: $75-78$

POSPÍŠIL, Z., MENŠÍK, J., TƯMOVÁ, B., ŠTUMPA, A., ČERNÝ, M. 1973: Experimental infection of colostrum-deprived, specific-pathogen free piglets with A-Hong Kong- (H3N2) influenza virus. Zbl. VetMed. B 20: $139-152$

SCHOLTISSEK, C., LUDWIG, S., FITCH, W.M., 1993: Analysis of influenza A virus nucleoprotein for the assessment of molecular genetic mechanisms. Arch. Virol. 131: 237-250

ŠESTÁK, K., 1992: unpublished data

TƯMOVÁ, B., MENŠÍK, J., ŠTUMPA, A., FEDOVÁ, D., POSPÍŠIL, Z. 1976: Serological evidence and isolation of a virus closely related to the human A/Hong Kong/68 (H3N2) strain in swine populations in Czechoslovakia in 1969-1972. Zbl. VetMed. B 23: 590-603

TƯMOVÁ, B. VĚŽNíKOVÁ, D., MENŠíK, J., ŠTUMPA, A. 1980: Surveillance of influenza in pig herds in Czechoslovakia in 1974-1979. Zbl. VetMed. B 27: 517-523

WEBSTER, R.G., BEAN, W.J., GORMAN, O. T., CHAMBERS, T.M., KAWAOKA, Y., 1992: Evolution and ecology of influenza A viruses. Microbiol. Rec. 56: 152-159 